\title{
TINJAUAN HUKUM ISLAM TERHADAP AKAD SEWA MENYEWA RUMAH KONTRAKAN \\ (Studi Kasasu : Kelurahan Sario Tumpaan Lingkungan V Kecamatan Sario Kota Manado) \\ Oleh : Nurhikma Djufri
}

\begin{abstract}
ABSTRAK
Tulisan ini membahas tentang tinjauan hukum islam terhadap akad sewa menyewa rumah kontrakan di kelurahan Sario Tumpaan Lingkungan V Kecamatan Sario, Kota Manado. Penulis tertarik melakukan penelitian ini untuk memperoleh gambaran tentang akada sewa menyewa rumah kontrakan yang di timjau dari hukum islam.

Adapun tujuan penelitian ini adalh untuk mengetahui akad sewa menyewa rumah kontrakan di Kelurahan Sario Tumpaan Lingkungan V Kecamatan Sario, dan untuk menganalisan dari sudut pandang hukum islam tentang akadd sewa menyewa rumah kontrakan diklurahan Sario Tumpaan Lingkungan V Kecamatan Sario.
\end{abstract}

Untuk mendapat jawaban atas permasalahan penelitian, penulis melakukan penelitian dengan menggunakan metode penelitian lapangan yang bertitik tolak pada deskriptif kualitatif, dimana penulis berusaha melukiskan fenomena yang terjadi berdasarkan fakta/kenyataan yang ada berupa kata-kata dan bukan angka.

Hail penelitian ini mengenai akad sewa menyewa rumah kontrakan tersebut, sudah sesuai dengan orang yang menyewakan, orang yang menyewa dan ada barang atau rumah yang disewakan, dalam hal tersebut semua diperrlukan penjelasan-penjelasan baik mengenai rumah dan jangka waktu yang disepakati oleh penyewa dan yang menyewakan kapan waktu berakhirnya sewa-menyewa, karena sewa menyewa hanya menggunakan fungi atau manfaat dari barang atau benda yang disewakan tanpa memiliki barang atau benda tersebut, jadi rumah tetap milik orang yang menyewakan tetapi menfaatmnya digunakan oleh orang yang menyewa dengan memeberikan imbalan berupa upah dengan ketentuan waktu dan besarnya biaya sewa tergantung kesepakatan orang yang 
menyewakan dan orang yang menyewa barang atau ruman yang disewakan di rumah tersebut.

\section{A. Pendahuluan}

Allah SWT, menciptakan satu sifat saling membutuhkan antara satu dengan yang lainnya, sehingga ,manusia tidak dapat hidup sendiri tanpa adanya bantuan dari orang lain. Sudah menjadi ketentuan Allah swt, bahwa manusia tidak mungkin mampu memebuhi kebutuhan mereka sendiri. Oleh karena itu, Allah memberikan inspirasi (Ilham) kepada manusia untuk mengadakan penukaran dalam bidang muamalah baik dari bidang jual belih, sewa menyewa, maupun kegiatan muamalah lainnya. Manusia dapat berdiri dengan lurus dan kehidupan ini berjalan dengan baik dan produktif. (Muhammad Yusuf Qardawi, 1993, 348).

Dalam bermuamalah manusia telah diberi keleluasaan untuk menjalankan. Namun, keleluasaan itu bukan berarti semua cara dapat dikerjakan. Untuk menjamin keselarasan dan keharmonisan antar sesama dibutuhkan adanya kerelaan dalam bermuamalah. Dalam konsep islam, manusia merupakan cerminan nilai di bidang muamalat, hukum muamalat bersumber dari Al-Qur'an, sunnah Rasul dan Ra'yu atau Ijtihad. (Ahmad Azhar Basyir, 2000, 13)

Muamalah itu adalah sema hukum syari'at yang bersangkutan dengan urusan dunia, dengan memandang kepada aktifitas hidup seseorang seperti jual-beli, tukarmenukar, pinjam-meminjam, sewa-menyewa dan sebagainya. Muamalah juga adalah tatacara atau peraturan dalam perhubungan manusia sesama manusia untuk memenuhi keperluan masing-masing yang berlandaskansyari'at Allah swt. Yang melibatkan bidang ekonomi dan social Islam. Muamalah yang dimaksut adalah dalam bidang ekonomi dan menjadi tumpuan seseorang yang memperoleh kesenangan hidup di dunia dan kebahagiaan di akhirat. 
Dalam Islam , sewa menyewa di istilahkan dengan al-Ijarah. Ijarah merupakan bentuk muamalah yang telah di atur oleh syariat islam. Sewa menyewa menjadi praktek muamalah yang masih banyak kita jumpai dalam kehidupan sehari-hari hingga saat ini. Secara etimologi, ijarah berarti "upah" atau "ganti" atau "imbalan". Sedangkan ijarah secara terminology yaitu pengambilan manfaat dari suatu benda dengan jalan penggantinya. (Helmi Karim, 1993, 52)

Dari pengertian di atas terlihat bahwa yang dimaksut dengan sewa menyewa yaitu pengambilan manfaat sesuatu benda, jadi dalam hal ini bendanya tidak berkurang sama sekali, dengan perkataan lain dengan terjadinya peristiwa sewa menyewa, yang berpindah hanyalah manfaat dari yang disewakan tersebut, dalam hal ini dapat berupa manfaat barang seperti kendaraan, rumah, dan manfaat karya seperti music, bahkan dapat juga berupa karya pribadi seperti pekerja. (Pasaribu, 1994, 52).

Rumah kontrakan merupakan salah satu bagian terpeting dari fenomena perumahan di Indonesia, terlebih dikalangan yang mempunyai pendapatan rendah dari segi ekonomi, namun, perumahan yang ditenpati oleh masyarakat yang pendapatannya rendah berkualitas buruk.

pemerintah bukan tidak memiliki solusi dalam mengatasi fenomena tersebut, namun hal yang mengherankan adalah banyak pemukiman kumuh yang akan didisiplinkan ternyata memiliki sertifikan tanah dan bangunan yang resmi, bahkan sertifikan hak milik yang sebenarnya keluar jika rumah tersebut layak huni.

dalam islam, sewa menyewa biasa disebut dengan Ijarah semua barang yang mungkin diambil manfaat atau jasanya saja. Barang yang disewakan dianggap sah apabilah kemanfaatannya dapat ditentukan dengan salah satu dari dua perkara yaitu: masa dan perbuatan/tenaga.

Ijarah dapat diartikan melakukan akada dengan mengambil manfaat barang atau jasa yang diterima dari orang lain dengan cara membayar sesuai dengan kesepakatan yang telah ditentukan. Ijarah tidak akan batal dengan meninggalkan salah satu dari 
berakad. Akan tetapi bisa batal karena rusaknya barang yang disewakan.(www.sosbud.kompasiana.com, 21 Juni 2013).

Ijarah adalah pemindahan hak guna (manfaat) atas barang atau jasa melalui pembayaran upah sewa tanpa di ikuti denghan pemindahan kepemilikan atas barang atau jasa tersebut.

Sewa menyewa yang dilakukan harus membawa manfaat bagi kedua belah pihak dan tidak merugikan. Aktifitas sewa menyewa juga harus dilandasi oleh rasa suka sama suka. Apabilah tidak ada persetujuan dari pihak penyewa dan orang yang menyewakan di anggap tidak sah karena bisa sajja keputusan yang di ambil hanyalah satu keinginan dari salah satu pihak. Uang muka bisa merugikan salah satu pihak dan mengurangi tujuan mencikptakan kemaslahatan bagi sesame umat. Padahal islam mengajarkan agar saling tolong menolong dalam berbuat kebaikan dan bukan pada perbuatan yang merugikan orang lain.

Sebagaimana Alla swt, berfirman dalam QS. Al-Maidah ayat 1:

Artinya:

Hai orang-orang yang beriman! Penuhilah janji-janji, janji disini adaalh janji setiap hamba kepada Allah dan perjanjian yang dibuat oleh manusia dalam pergaulan sesamanya.

Penerapan panjar dalam sewa menyewa rumah kos sudah lama dilakukan terhadap semua calon penyewa rumah kos dari segala kalangan. Calon penyewa diwajibkan segerah membayar atau membatalkan transaksi. Akan tetapi selama ini belum ada surat perjanjian, atau bukti outentik terhadap pelaksanaan transaksi pembayaran panjar tersebut. Calon penyewa tidak bisa berbuat apa-apa, karena harus menuruti besar panjar yang ditentukan pihak pengelolah rumah kos.(Aisyatu Nadlifah, 2009) 


\section{B. RUMUSAN DAN BATASAN MASALAH}

berdasarkan latar belakang yang telah diuraikan sebelumnya di atas maka penulis dapat mengemukakan dan merumuskan inti masalah tersebut yakni "bgaimana tinjauan hukum islan terhadap akad sewa menyewa kontrak (Studi Kasus: Sario TUmpaan Link. V Kota Manado)?

Berdasarkan rumusan dan batasan masalah tersebut penulis membagi dan membuat kedalam sub pokok masalah sebagai berikut :

1. Bagaimana akad sewa menyewa rumah kontrakan di Sario Tumpaan Link. V?

\section{Pengertian akad}

dalam istilah fiqh, secara umum akad berarti sesuatu yang menjadi tekad seseorang unutk melaksanakan, baik yang muncul dari satu pihak, seperti wakaf, talak, dan sumpah, maupun yang muncul dari dua pihak, seperti jual belih, sewa, wakalah, dan gadai. Secara kusus akad berarti ketertarikan antara ijab (peryataan/penawaran/ pemindahan kepemilikan) dan qabul pernyataan penerimaan kepemilikan) dalam lingkup yang disyari'atkan dan berpengaruh pada sesuatu.

Menurut ulama Hanafiyah, rukun ijarah adalah ijab dan qabul, antara lain dengan menggunakan kalimat: al-ijarah, al-ikti'ra, dan al-ikra, adapun menurut jumhur ulama rukun ijarah ada empat yaitu: Aqid (orang yang akad), Sighat akad (pelaku akad), Ujrah (upah), manfaat.

Syarat alam aka dada empat, yaitu: il'iqod, (syarat berlakunyaakad), Shihah (syarat sahnya akad), An-Nafadz (syarat pelaksanaan), syarat Lazim. Syarat in-Iqod ada

yang umum dan khusus. Syarat umum harus selalu ada pada setiap akad, seperti syarat yang harus ada pelaku akad, objek akad dan sShighah akad, akad bukan pada sesuatu yang diharamkan, dan akad pada sesuatu yang bermanfaat.sementara itu, syarat khusus merupakan sesuatu yang harus ada pada akad-akad tertentu, seperti syarat minimal dua saksi pada akad nikah. Syarat Shihah yaitu syarat yang diperlukan secara syariah agar 
akad berpengaruh, seperti dalam akad perdagangan harus bersi dari cacat, keabsahan syaat Nafadz ada dua, yaitu kepemilikan (barang dimiliki oleh pelaku dan berhak menggunakannya) dan wilayah, syarat Lazim, yaitu bahwa akad harus dilaksanakan apabila tidak ada cacat.(Ascarya, 2007, 35)

\section{Pengertian sewa-menyewa}

Sewa adalah pemakaian sesuatu dengan membayar uang atau uang yang dibayarkan karena memakai atau meminjam sesuatu, penghasilan yang diterima atau diperoleh sehubungan dengan kesepakatan untuk memberikan hak menggunakan harta selain tanah dan atau bangunan selama jangka waktu tertentu baik dengan perjanjian tertulis maupun tidak tertulis sehingga harta tersebut hanya dapat digunakan oleh penerima hak selama jangka waktu yang telah disepakati. Sedangkan menyewa adalah memakai (meminjam, menampung) dengan membayar uang sewa. Sewa menyewa dalam bahasa arab di istilahkan dengan al-ijarah. Menurut pengertian hukum islam, sewa menyewa diartikan sebagai suatu jenis akad untuk mengambil manfaat dengan jalan penggantian.(Lubis dan Farid, 2012, 144)

Dari pengertian di atas terlihat bahwa yang dimaksut dengan sewa menyewa adalah pengambilan manfaat sesuatu benda. Jadi, dalam hal ini benda tidak berkurang sama sekali. Dengan perkataan lain, terjadinya sewa menyewa, yang berpindah hanyalah manfaat dari benda yang disewakan tersebut, dalam hal ini dapat berupa manfaat barang seperti kendaraan, rumah dan manfaat karya seperti pemusik, bahkan dapat juga berupa karya pribadi seperti pekerja.

Dalam istilah hukum islam, orang yang memnyewakan disebut mu'Ajjir, sdangkan orang menyewa disebut musta'jir, benda yang disewakan diistilahkan ma'jur dan uang sewa atau imbalan atas pemakaian manfaat barang disebut ajran atau ujrah.

Sewa menyewa sebagaimana perjanjian lainnya, merupakan perjanjian yang bersifat konsesual (kesepakatan). Perjanjian itu mempunyai kekuatan hukum, yaitu pada 
saat sewa menyewa berlangsung. Apabila akad sudah berlangsung, pihak yang menyewa (mu'ajjir) wajib menyewakan barang (ma'jur) kepada penyewa (musta'jir), dengan diserahkannya manfaat barang/benda maka penyewa wajib pula menyerahkan uang sewanya. (Lubis dan Farid, 2012, 145)

\section{Dasar huku sewa-menyewa}

Sebagaimana Allah swt. Berfirman dalam Qs. Al-Baqarah ayat 233 sebagai berikut:

Artinya:

Dan jika kamu ingin anakmu disusukan oleh orang lain, maka tidak ada dosa bagimu apabila kamu memberikan pembayaran menurut yang patut. Bertaqwalah kamu kepada Allah dan ketahuilah bahwa Allah maka melihat apa yang kamu kerjakan.

Berdasarkan ayat di atas menjadi dasar hukum adanya system dewa dalam hukum islam, seperti yang di ungkapkan dalam ayat bahwa seseorang itu boleh menyewa orang lain untuk menyusui anaknya, tentu saja ayat ini akan berlaku umum atau global terhadap segala bentuk sewa menyewa.(Mardani, 2012, 248)

Nabi Muhammad saw. Bersabda:

Artinya:

Hanzholah Ibnu Qais Radiallaahu 'anhu berkata: aku bertanya keepada Rafi' Ibnu Khadij tentang menyewakan tanah dengan emas dan perak. Ia berkata: tidak apaapa. Orang-orang pada zaman Rasulullah Sallallahu 'alaihi wa sallam menyewakan tanah dengan pepohonan yang tumbuh di tempat perjalanan air, pangkal-pangkal parit, dna aneka tumbuhan. Lalu dari tetumbuhan itu ada yang hancur dan ada yang slamat. Sedang orang-orang yang tidak mempunyai sewaan lainnya kecuali ini. Maka Rasulullah Sallallahu alaihi wa sallam melarang hal itu. Adapun imbalan dengan barang yang 
nyata dan terjamin, maka tidak apa-apa. Riwayat Muslim (Al-Asqolany, Bandung AlHdayah, T.th, 332)

Berdasarkan penjelasan hadis di atas, bahwa Rasulullah Muhammad SAW, telah membolehkan praktek sewa menyewa tanah dengan emas dan perak yang sesuai dengan imbalan yang telah disepakati bersama. Akan tetapi apabilah terjadi perubahan dengan tidak menunaikan imbalan dalam hal demikian, begitu juga dalam hal sewa menyewa barang yang nyata dan harus terjamin sesuai dengan fungsi dari barang yang disewa.

\section{Syarat-Syarat dan Rukun Sewa Menyewa}

Diantara syarat barang sewa adalah dapat dipegang atau dikuasai. Hal ini didasarkan pada hadis Rasulullah yang melarang barang yang tidak dapat dipegang atau dikuasai, sebagaimana dalam jual beli.(Syafei,2006, 129)

Adapun syarat-syarat berkaitan dengan barang disewakan adalah:

1. Mengetahui bentuk barang sewaan. Hal ini dapat dilakukan dengan cara menjelaskan tempatnya. Maka dari itu, tidak sah menyewakan salah satu diantara dua rumah, tanpa menunjukan secara pasti rumah yang akan disewakan.(Al-Bugha, 2009, 155)

2. Menhetahui jenis dan sifat manfaat, hal ini dilakukan ketika barang sewaan dapat dimanfaatkan secara berbeda-beda yang secara adat memang tidak ada kebiasaan pemanfaatan khuus. Tidak sah sewa menyewa tanah tanpa memberitahukan tanaman yang akan ditanam karena pengaruh tanaman terhadap tanah akan berbeda-beda, bergantung pada jenis tanamannya, atau menyewa rumah untuk tempat tinggal, penyewa tidak dipersyaratkan untuk menjelaskan siapa saja keluarga yang akan tinggal bersamanya atau barangbarang apa saja yang akan dismpan di rumah itu.

3. Mengetahui kadar manfaat. Ukuran manfaat berbeda-beda, bergantung pada jenisnya, ada manfaat yang dapat diukur berdasarkan waktu, kadar manfaat 
yang diukur bedasarkan waktu. Kadar manfaat jenis ini adalah yang tidak dapat diukur selain dengan ukuran waktu. Pemanfaatannya bisa lama atau sebentar, bisa juga banyak atau sedikit. Contohnya adalah menyewa rumah untuk tempat tinggal. Menempati rumah bisa sebentar, bisa juga lama.

Rukun sewa mneyewa ada dua yaitu: 1) Mu'Jir, dan Musta'Jir, 2) Shigat, Mu'Jir adalah orang yang memberikan upah. Sedangkan Muta'jir adalah orang yang menerima upah. Shigat adalah ijab dan qabul antara Mu'jir dan Musta'jir, Musta'jir dibolehkan menyewa bagi barang sewaan kepada orang lain ddengan syarat penggunaan barang itu sesuai dengan penggunaan yang dijanjikan ketika awad. Sewa menyewa berlangsung atas manfaat yang berasal dari benda tertentu yang disebut cirri-cirinya.(Al-Fauzan, 2009, 428)

Adapun rukun yang berkaitan dalam sewa menyewa Mu'Jir (orang yang menyewakan) dan Musta'Jir (orang yang menerima upah) adalah sebagai berikut:

1. Mu'Jir adalah orang yang menyewakan sesuatu wajib berusaha semaksimal mungkin agar penyewa dapat mengambil manfaat dari apa yang ia swakan. Misalnya, melengkapi rumah yang ia sewakan dengan segala perabotnya, memperbaiki kerusakan-kerusakan di dalamnya, dan mempersiapkan semua yang diperlukan dalam memanfaatkan rumah teresebut.

Musta'Jir adalah penyewa, ketika selesai menyewa, wajib menghilangkan semua yang terjadi karena perbuatannya. Kemuian menyerahkan apa yang ia sewa sebagaimana ketika menyewakan.

2. Shigat ijab qabul antara Mu'jir dan Musta'Jir misalnya: orang yang menyewakan wajib menyerahkan benda yang disewakan kepada penyewa dan memberinya keleluasan untuk memanfaatkannya. Apabila ia menghalangi penyewa untuk memanfaatkan bendah yang diseawkan selama masa sewa atau dalam sebagian masa sewa, maka penyewa tidak berhak mendapatkan bayaran dari penyewa tersebut, atau tidak berhak mendapatkan bayaran secara utuh. 
Hal ini dikarenakan ia tidak memenuhi apa yang harus ia lakukan dalam aqad ijarah, sehingga ia tidak berhak mendapatkan apa-apa. Apabila orang yang menyewakan memberikan keleluasaan kepada penyewa untuk memanfaatkan barang yang disewakan , namun si penyewa membiarkannya selama masa penyewa atau dalam sebagian masa penyewaan, maka ia tetap harus menyerahkan bayarannya secara utuh. Karena Ijarah adalah akad yang wajib atas kedua bela pihak, maka dituntut terlaksananya hal-hal yang harus terwujud di dalamnya, yaitu kepemilikan orang yang menyewakan terhadap bayaran dan kepemilikan penyewa terhadap manfaat.(Saleh, 2005, 485)

\section{Kewajiban Pihak Yang Menyewakan dan Pihak Yang Menyewa}

Ada beberapa kewajiban dalam sewa menyewa yang harus dipenuhi oleh pihak yang menyewakan adalah:

1. Menyewkan barang atau bendah yang disewakan kepada si penyewa;

2. Memelihara barang yang disewakan sedemikian rupa sehingga dapat dipakai untuk keperluan yang dimaksutkan;

3. Memberikan kepada si penyewa kenikmatan tentram dari barang atau benda yang disewakan selama berlangsungnya persewaan.(Faisal Salam, 2006, 121)

Sedangkan kewajiban pihak si penyewa mempunyai kewajiban yang harus dipenuhi antara lain yaitu:

1. Memakai barang atau benda yang disewa dengan tujuan yang diberikan kepada barang atau bendah itu menurut perjanjian sewanya.

2. Membayar harga sewa pada waktu-waktu yang telah ditentukan menurut perjanjian.

\section{Pengembalian objek sewa menyewa}


Apabilah masa yang telah ditetapkan dalam perjanjian telah berakhir, maka penyewa berkewajiban untuk mengembalikan barang yang disewanya kepada pemilik semula (yang menyewakan). Adapun ketentuan pengembalian barang objek sewa menyewa adalah:

1. Apabila objek sewa menyewa dikualifikasikan sebagai barang tidak bergerakmaka penyewa wajib mengembalikan kepada pihak yang menyewakan dalam kosong. Maksutnya, tidak ada harta pihak di dalamnya. Misalnya, dalam perjanjian sewa menyewa rumah.

2. Apabila yang menjadi objek perjanjian sewa menyewa adalah barang yang bewujud tanah maka penyewa wajib menyerahkan tanah kepada pemilik dalam keadaan tidak ada tanaman penyewa di atasnya.(Suharwardi, Op, Cit, 162)

3. Apabila barang yang menjadi objek perjanjian merupakan barnag bergerak maka penyewa harus mngembalikan barang itu kepad ayang menyewakan/pemilik dengan menyerahkan langsung bendanya. Misalnya, sewa menyewa kendaraan.

Ketika penyewaan berakhir, wajib atas penyewa untuk mengembalikan barang yang disewakan. Apabila barang tersebut adalah barang yang bergerak maka dia harus menyerahkan kepada pemiliknya. Apabila barang tersebut adalah rumah maka ia harus mengosongkan dari barang-barangnya, dan apabila barang tersebut adalah tanah pertanian maka ia harus membersihkannya dari tanaman. Kecuali apabila ada uzur sebagaimana yang telah dijelaskan di atas, maka tanah tersebut tetap berada di tangan penyewa sampai dia memanen tanaman, dengan membayar sewa yang wajar.

Adapun para ulama mazhab Hanbali berpendapat bahwa ketika penyewaan berakhir, penyewa dapat berlepas tangan. Dia tidak berkewajiban untuk mengambilkan barang sewaan dan menanggung bebannya, sebagaimana barang titipan karena penyewaan adalah akad yang tidak menetapkan tanggung jawab sehingga ia tidak menetapkan kewajiban untuk mengembalikan barang sewaan dan menanggung bebannya. Menurut mereka, setelah masa penyewaan berakhir, barang sewaan menjadi amanat di 
tangan penyewa. Apabila barang tersebut rusak tanpa disebabkan oleh kelalaiannyamaka dia tidak wajib menggantinya.(Sayyid Sabiq, Op,Cit, 161)

\section{Pembahasan}

Sewa menyewa adalah suatu perjanjian atau kesepakatan dimana penyewa harus membayarkan atau memberikan imbalan atau manfaat dari benda atau barang dari yang dimiliki oleh pemilik-pemilik barnag yang di pinjam dalam sewa menyewa adalah muba atau diperbolehkan. Dalam sewa menyewa harus ada barang atau benda yang disewakan, penyewa, pemberi sewa, imbalan dan kesepakatan antara pemilik barang dan yang menyewa barang. Berikut ini akan peneliti uraikan tentang akad sewa menyewa rumah kontrakan yaitu dilokasi peneliti yang peneliti lakukan bertempat di Kelurahan Sario Tumpaan Lingkungan V Kecamatan Sario Kota Manado antara lain sebagai berikut:

\section{Akad Sewa Menyewa Rumah Kontrakan di Kelurahan Sario Tumpaan Lingkungan V Kecamatan Sario Kota Manado}

Sewa menyewa pada dasarnya hampir sama dengan jual beli, perbedaannya terletak pada kepemilikannya, yaitu sewa menyewa benda tidak dapat dimiliki atau atau hanya hak pakai, sedangkan pada jual beli barang atau bendanya dapat dimiliki atau hak milik. Sewa menyewa menurut Syariat Islam mengandung pengertian menyewakan sesuaut kepada orang lain unutk diambil manfaatnya dengan membayar sejumlah uang sebagai ongkos atau ganti benda yang disewakan. Sewa menyewa adalah suatu perjanjian atau kesepakatan dimana pihak penyewa harus membayarkan atau memberikan imbalan atau manfaat dari benda atau barang yang dimiliki oleh pemilik barang yang dipinjamkan.

Penyewa dalam mengembalikan atau asset yang disewa harus mengembalikan barang secara utuh seperti pertama kali dipinjam tanpa berkurang maupun bertambah, kecuali ada kesepakatan lain yang disepakati saat sebelum barang berpindah tangan. Keterlibatan manusia dalam aktifitas bisnis tidak semata karena factor pemenuhan kebutuhan fisik, tapi pembinaan komunikasi positif, perilaku mutualis (saling 
menguntungkan), realisasi keadlian, dan perilaku tidak saling merugikan, merupakan sebagian dari sekian banyak factor krusial bagi terciptanya tatanan kehidupan manusia.(idris dan titik, 2008, 1)

Laju perkembangan perekonomian semakin cepat sejalan dengan laju informasi dan tegnologi yang semakin maju. Kemajuan inilah menjadi tantangan baru bagi umat islam agar tidak ketinggalan terhadap perkembangan tersebut tanpa melupakan kemuslimannya dalam arti kemajuan ini tentu haruslah dapat didukung keimanan dan keilmuan karena, dengan ini maka seorang muslim dapat melewati hidup ini dengan selamat.

Berdasarkan penjelasan di atas, maka penulis mendapatkan sewa menyewa menurut Syariat Islam mengandung pengertian menyewakan sesuatu kepada orang lain untuk diambil manfaatnnya dengan membayar sejumlah uang sebagai ongkos atau ganti barang yang disewa. Sewa menyewa adalah salah satu tolong menolong kepada orang lain yang membutuhkan, apabilah pada zaman sekarang, kehidupan semakin sulit, kebutuhan sangat banyak sementara uang tidak cukup untuk membeli sendiri. Dari hal itu keberadaan hak guna pakai yang dapat digunakan untuk kebutuhan sehari-hari. Disamping itu rumah kontrakan mempunyai manfaat yang mendasar yatu saling menguntungakan satu dengan yang lainnya. Banyak kalangan diantaranya yang menyewa rumah yaitu pendatang dari luar daerah untuk membuka usaha tentunya memerlukan rumah kontrakan guna membantu biaya kontrakannya.

\section{a. Syarat dan Akad Sewa Menyewa Rumah Kontrakan}

Dalam hal syarat sewa menyewa rumah, maka kami dari pihak pengelola rumha kontrakan memintakan identitas yang lengkap kepada penyewa yaitu kartu penduduk atau KTP, Kartu Keluarga (KK) bagi yang sudah berkeluarga, kwitansi dan materai 6.000, apabila semuanya telah terpenuhi, maka kami akan memberikan kunci rumah kami untuk dipakai oleh penyewa. Kemudian kami memberitahukan harga sewa menyewa rumah dan biaya listrik yang dibebani kepada penyewa seperti table dibawah ini: 
Tabel. 1

Biaya Sewa Menyewa dan Listrik

\begin{tabular}{|c|c|c|c|}
\hline Nama Pemilik & $\begin{array}{c}\text { Harga Sewa } \\
\text { Perbulan }\end{array}$ & $\begin{array}{c}\text { Harga Sewa } \\
\text { Pertahun }\end{array}$ & $\begin{array}{c}\text { Biaya Listrik dan } \\
\text { PDAM Perbulan }\end{array}$ \\
\hline $\begin{array}{c}\text { Djufri } \\
\text { Marni Ichsan } \\
\begin{array}{c}\text { Budi Lamatenggo } \\
\text { Sri Rahayu } \\
\text { Marfan Arifadi Padina }\end{array}\end{array}$ & Rp. 1.500.000,- & - & - \\
& Rp. 20.000.000,- & Rp. 500.000,- \\
& Rp. 30.000.000,- & Rp.500.000,- \\
& Rp. 20.000.000,- & Rp. 500.000,- \\
\hline
\end{tabular}

\section{Keterangan :}

1. Djufri menanggung beban biaya tagihan Listrik dan PDAM (Air)

2. Marni Ichsan Menanggung beban biaya Listrik dan PDAM (air) kepada sipenyewa.

3. Budi Lamatenggo menanggungkan beban biaya Listrik dan PDAM (air) kepada sipenyewa.

4. SriRahayu Menanggung beban biaya litrik dan PDAM (air) kepada sipenyewa.

5. Marfan Arifadi Padina Menanggung biaya listrik dan PDAM (air) kepada sipenyewa.

Setelah terjadi persetujuan dari poenyewa tentang harga, disitulah terjadi akad maka kami akan menyerahkan kunci rumha sesuai dengan kesepakatan kedua bela pihak. Kemudian dari harga sewa rumah tersebut terserah apakah rumah tersebut ditempat tinggalkan sekaligus dengan membuka usaha. Oleh karena itu, setelah terjadi persetujuan dari kedua bela pihak maka kami memeriksa kembali keutuhan rumah tersebut agar tidak terjadi kesalah pahaman diantara kedua bela pihak, kemudian itu disetujui maka dari 
pihak pengelolah menguasakan rumah tersebut untuk di tempati sebagaimana mestinya. (hasil wawancara, 11 Oktober 2013)

Sebelum rumah ini ditempati oleh penyewa ada beberapa hal yang dilakukan oleh kami selaku pemilik yaitu dengan memeriksa kambali keutuhan rumah agar pemakai dapat merasakan kenyamanan untuk menempatinya.(Hasil wawancara, 12 Oktober 2013)

Jumhur ulama menegaskan bahwa perjanjian sewa-menyewa tersebut tidak menjadi batal dengan meninggalnya salah satu pihak yang melakukan perjanjian. Namun demikian, tidak tertutup kmungkinan adanya pembatalan perjanjian sewa-menyewa oleh salah satu pihak jika ada alasan yang kuat untuk itu.

Ada beberapa kewajiban dalam sewa menyewa yang harus dipenuhi oleh pihak yng menyewakan:

1. Menyewakan barang yang disewakan kepada si penyewa;

2. Memelihara barang yang disewakan sedemikian rupa sehingga dapat dipakai untuk keperluan yang dimaksutkan;

3. Memberikan kepada sipenyewa kenikmatan, kenyamanan dan ketentraman dari barang atau benda yang diseakan selama berlangsungnya persewaan.

Sedangkan kewajiban pihak yang si penyewa mempunyai kewajiban yang harus dipenuhi antara lain:

1. Memakai barang yang disewa sebagai dengan tujuan yang diberikan kepada barang itu menurut perjanjian sewanya.

2. Membayar harga sewa pada waktu-waktu yang telah ditentukan menurut perjanjian.(Moch, 2006, 121)

Barang sewa boleh dimanfaatkan oleh orang lain dengan syarat-syarat berikut: 
1. Hendaknya, orang yang diserahkan barang sewaan dapat menggunakannya secara amanah.

2. Hendaknya, ia mempergunakannya untuk jenis pemanfaatan yang sama dengan penyewa atau yang lebih kecil resikonya terhadap barang sewaa itu.

3. Bila seseorang menyewa rumah untuk dijadikan tempat tinggal, ia tidak boleh menyerahkannya kepada orang lain untuk digunakan sebagai pabrik atau tempat berdagang. (Moch, 2006, 121)

\section{b. Resiko-resiko Dalam Sewa Menyewa}

Aadapun yang menyangkut penyewaan rumah kontrakan dari kami pihak pemilik rumah kontrakan dan dari pihak sipenyewa. Yang menyangkut resiko dari pemilik kontrakan yaitu apabila terjadi kerusakan rumah dengan cara tidak sengaja dalam waktu penyewaan atau terjadi secara tiba-tiba kerusakannya ketika sipenyewa kontrakan sudah menempati maka kami akan memperbaiki dari kerusakan tersebut. Dengan kata lain kerusakan yang terjadi menjadi kewajiban dari si penyewa rumah kontrakan unutk memperbaikinya, dan ini berlaku bagi semua kontrakan yang berada di Kelurahan Sario Tumpaan Lingkungan V.(Hasil wawancara, 15 Oktober, 2013).

\section{c. Pembatalan dan Perakhirnya Sewa Menyewa}

Akibat batalnya sewa menyewa rumah terjadi karena rumah kontrakan tersebut terjadinya kebakaran secara dengan tidak sengaja. Pembatalan terjadi ketika di saat rumah terbakar, dan sipenyewa belum lama memakainya. Maka kami dari pihak pemilik rumah, mengembalikan uang sewanya setengah dari harga seutuhnya yang didalamnya terjadapat uzur.(hasil wawancara, 16 Oktober 2013)

Demikian juga halnya dengan penjualan objek perjanjian sewa menyewa yang tidak menyebabkan putusnya perjanjian yang di adakan sebelumnya. Meskipun demikian, 
tidak tertutup kemungkinan pembatalan perjanjian (pasakh) oleh salah satu pihak ada alasan/dasar yang kuat.

Adapun hal-hal yang menyebabkan batalnya perjanjian sewa menyewa adalah disebabkan hal-hal:

1. Rusaknya barang yang disewakan

2. Rusaknnya barang yang diupahkan (M a'jur a'laih)

3. Terpenuhinya manfaat yang diakadkan

4. Adanya Uzur

Pada dasarnya perjanjian sewa menyewa merupakan perjanjian yang lazim,masing-masing pihak yang terikat pada perjanjian tidak berhak membatalkan perjanjian (tidak mempunyai hak pasakh) karena termasuk perjanjian timbal balik. Bahkan, jika salah satu pihak (yang menyewakan atau penyewa) meninggal dunia, perjanjian sewa menywa tidak akan menjadi batal, asal yang mnejadi objek sewa masih ada. Sebab dalam hal satu pihak meninggal dunia, maka kedudukannya digantikan oleh ahli warisnya.

Berdasarkn hasil wawancara di atas maka penulis mendapatkan manfaat sewa menyewa di tengah-tengah masyarakat adalah memupuk rasa tolong menolong, menghilangkan sifat kikir dan memperhatikan kepentingan orang lain, akan tetapi kita harus terus menjaga kerukunan, persatuan dan perasaan bermusuhan, untuk itu syariat islam mengajarkan kepada kita bahwa sewa menyewa itu diperbolehkan asal pada batasbatas kewajaran jangan sampai mengorbankan pihak-pihak tertentu.

\section{Kesimpulan}

Berdasarkan pembahasan di atas mak penulis menyimpulkan bahwa: 
1. Hasil penelitian penuli menunjukan bahwa mengenai teori sewa menyewa rumah kontrakan dalam pandangan hukum islam bahwa sewa menyewa adalah menyewakan sesuatu kepada orang lain untuk di ambil manfaatnnya dengan membayar sejumlah uang sebagai ongkos atau ganti benda yang disewa. Sewa menyewa adalah salah satu menolong kepada orang lain yang sangat membutuhkan tempat tinggal, apabila zaman sekarang ini, kehidupan semakin sulit, kebutuhan sangat banyak, sementara uang tidak cukup untuk membeli sendiri.

2. Mengenai akad sewa menyewa di Kelurahan Sario Tumpaan Lingkungan V Kecamatan Satio Kota Manado sudah sesuai dengan hukum Islam, ini dilihat dari rukun dan syarat dalam akad sewa menyewa. Mengenai masalah keuntungan yang di dapat dari hasil usaha rumah kontrakan sesuai dengan konsep hukum Islam karena keuntungan yang diperoleh berasal dari hasil sewa rumah, sedangkan masalah kerugian pada usahah rumah kontrakan akan terjadi kerugian apabila terjadi kebakaran, di karenakan arus pendek listrik ataupun sebab-sebab lainnya. 


\section{Daftar Psutaka}

Al-Bugha, Mustafa Dib., Fiqh Al-M u'awadhah (Buku Pintar Transaksi Syariah) (Jakarta: Hikmah, 2009).

Ash,Shiddieqy, Hasbi, Hukum-Hukum Fiqh Islam (Jakarta: Bulan Bintang, 1970)

Basyir,Azhar Ahmad, Asas-asas Hukum Muamalah (Hukum Perjanjian Islam), Yogyakata: UII Press, 2000.

Doi, ABdur Rahman I, Syariat Hukum Islam (Jakarta: PT. Raja Grafindo Persada, 1996)

Faisal Salam, Moch, Pertumbuhan Hukum Bisnis Syari'at di Indonesia (Bandung: Pustaka, 2006)

Mardani, Fiqh Ekonomi Syariah, (Jakarta : Graha Indonesia, 1999)

Pasaribu, Chairuman dan Suhrawardi K. Lubis, Hukum Perjanjian Dalam Islam, (Jakarta : Sinar Grafika Offset, 1994)

Subekti, Pokok-Pokok Hukum Perdata (Yogyakarta: Dana Bhakti Wakaf, 1995)

Syafei Rahmat., Fiqh Muamalah (Bandung : CV. Pustaka Setia, 2006)

Suhendi, Hendi. Fiqh Muamalah, (Jakarta : PT RajaGrafinndo Persada, 2002) 